\title{
Operation Strategies Based on Carbon Corrosion and Lifetime Investigations for High Temperature Polymer Electrolyte Membrane Fuel Cell Stacks
}

Kannan, A.; Kaczerowski, J.; Kabza, A.; Scholta, J.

Published in:

Fuel Cells

Link to article, DOI:

10.1002/fuce.201700096

Publication date:

2018

Document Version

Peer reviewed version

Link back to DTU Orbit

Citation (APA):

Kannan, A., Kaczerowski, J., Kabza, A., \& Scholta, J. (2018). Operation Strategies Based on Carbon Corrosion and Lifetime Investigations for High Temperature Polymer Electrolyte Membrane Fuel Cell Stacks. Fuel Cells, 18(3), 287-298. https://doi.org/10.1002/fuce.201700096

\section{General rights}

Copyright and moral rights for the publications made accessible in the public portal are retained by the authors and/or other copyright owners and it is a condition of accessing publications that users recognise and abide by the legal requirements associated with these rights.

- Users may download and print one copy of any publication from the public portal for the purpose of private study or research.

- You may not further distribute the material or use it for any profit-making activity or commercial gain

- You may freely distribute the URL identifying the publication in the public portal 


\section{Operation Strategies based on Carbon Corrosion and Lifetime Investigations for High Temperature Polymer Electrolyte Membrane Fuel Cell Stacks}

\begin{tabular}{|r|l|}
\hline Journal: & Fuel Cells \\
\hline Manuscript ID & fuce.201700096.R2 \\
\hline Wiley - Manuscript type: & Original Research Paper \\
\hline Date Submitted by the Author: & n/a \\
\hline Komplete List of Authors: & $\begin{array}{l}\text { Kannan, Arvind; DTU, Department of Energy Conversion and Storage } \\
\text { Kabza, Alexander; ZSW } \\
\text { Kaczerowski, Jürgen; ZSW Ulm } \\
\text { Scholta, Joachim; ZSW Ulm }\end{array}$ \\
\hline Keywords: & $\begin{array}{l}\text { HT-PEM fuel cell, Carbon corrosion, Start-stop, Lifetime Analysis, } \\
\text { Durability, Accelerated stress testing, Micro CHP, Degradation, Fuel Cell } \\
\text { Electrode }\end{array}$ \\
\hline & \\
\hline
\end{tabular}

\section{SCHOLARONE ${ }^{\text {m }}$}

Manuscripts 


\title{
Operation Strategies based on Carbon Corrosion and Lifetime Investigations for High Temperature Polymer Electrolyte Membrane Fuel Cell Stacks
}

\author{
Arvind Kannan ${ }^{1,2}$, Jürgen Kaczerowski ${ }^{1}$, Alexander Kabza ${ }^{1}$, Joachim Scholta ${ }^{* 1}$ \\ ${ }^{1}$ Zentrum für Sonnenenergie- und Wasserstoff-Forschung Baden-Württemberg (ZSW), \\ Helmholtzstr. 8, 89081 Ulm, Germany \\ 2 Department of Energy Conversion and Storage, Kemitorvet 207, Technical University of \\ Denmark, 2800 Kgs. Lyngby, Denmark \\ *joachim.scholta@zsw-bw.de, phone: +49/731/9530-206, fax: +49/731/9530-606
}

\begin{abstract}
This paper is aimed to develop operation strategies for high temperature PEM fuel cells stacks in order to enhance the endurance by mitigating carbon oxidation reaction. The testing protocols are carefully designed to suit the operating cycle for the realistic application. A 5 cell co-flow stack is assembled with BASF Celtec ${ }^{\circledR} \mathrm{P}$ membrane electrode assembly (MEA) with an active area of $163.5 \mathrm{~cm}^{2}$. The oxidation rate of carbon is systematically investigated employing potentiostatic experiments under variation of both cell voltage and temperature using on-line mass spectrometry.

The experimental results show that more $\mathrm{CO}_{2}$ is measured for the OCV operation, indicating that the lifetime of the stack is strongly affected by a factor of appr. $12-26$ between OCV and $700 \mathrm{mV}$ depending on temperature. Protective start-stop algorithms are developed to avoid the formation of aggressive cell potentials. The startup procedures let degrade the catalyst support to a higher extent than the stop procedures, which is presumably due to both OCV exposure and hydrogen front passing through the anode. A model for lifetime prediction is developed from carbon corrosion experiments and validated with a durability test for 1,562 cycle events.
\end{abstract}


Keywords: HT-PEM fuel cell, Carbon corrosion, Start-stop, Lifetime Analysis, Durability, Start-stop, Accelerated stress testing, micro CHP systems, Degradation, Fuel cell electrode

\section{Introduction}

Fuel cells have attracted much attention due to their promise as energy conversion devices for both mobile and stationary applications. For allowing a commercial use of these technologies, certain lifetime requirements have to be fulfilled, which is still a developmental issue for some of the possible HT-PEMFC applications. The US Department of Energy (DOE) provided 2020 operation time targets of 60,000 hours $\left(<25 \mathrm{~kW}_{\text {el. }}\right)$ and $80,000 \mathrm{~h}\left(>25 \mathrm{~kW}_{\text {el. }}\right)$ for stationary applications and 5,000 hours of operation, including 5,000 cycles for mobile applications, which leads to a request of a very limited performance decay [1]. The degradation of fuel cell components plays a vital role in the performance and lifetime of the fuel cell. Optimal parameters need to be found out in order to operate the fuel cell at its full potential and there involves a significant challenge in improving the lifetime of the HT-PEM fuel cells. Optimization of operation strategies is quite essential in mitigation of fuel cell degradation during start-stop events. Therefore, a profound knowledge both about the influence of decisive operating parameters and the involved degradation mechanisms is required.

One of the challenges in the development of membrane electrode assemblies is the practical impossibility to perform a comprehensive number of durability tests in the laboratory on component basis for the required lifetimes mainly due to time and test station constraints.

Since tests for several thousands of hours in order to find out if a component advancement can last that long are virtually impossible, rapid or accelerated aging tests are necessary which could help in investigating specific degradation modes in short time duration and being able to correlate these results with findings from realistic lifetime tests. For proper correlations 
between accelerating and realistic conditions, the degradation mode to be studied needs to be mechanistically well understood [2].

Transient conditions during start-stop events and also dynamic operation can result in a severe degradation of the fuel cell, which makes strategies to mitigate the impact important for achieving long term durability. Degradations induced by startup/shutdown has been understood [3, 4] and have been extensively studied [5-9] as these events, when not well managed, are known to be the most harmful regarding the stability of the PEMFC components [10-14]. Other common methods to accelerate the carbon corrosion are potential cycling, potential steps, potentiostatic holds [15-18] as well as thermally induced corrosion.

A short review on the mechanism of carbon oxidation reaction which is responsible for a large part of the degradation of performance and lifetime of the fuel cell is described in the following section.

\subsection{Carbon corrosion}

The carbon is first oxidized, forming oxidized carbon intermediates as revealed by the voltammetric $[15,16]$ and spectrometric studies $[19,20]$. The final step of corrosion is the formation of carbon dioxide, which is thermodynamically favorable at potentials higher than $0.2 \mathrm{~V}_{\text {vs. RHE. }}$ [4, 14-16] The kinetics in the carbon reactions is however quite slow, which means that the carbon is extensively stable at normal operating conditions with potentials between $0-0.8 \mathrm{~V}_{\mathrm{RHE}}$ of a PEM fuel cell [21]. Due to the resulting high overvoltage, one part of the governing Butler-Volmer equation can be neglected, and an exponential increase of carbon corrosion with increasing overpotential will occur [16]. During the startup or shutdown sequences, fuel starvation or reverse current situations, the local cathode potential can be even higher than $1.0 \mathrm{~V}_{\mathrm{RHE}}$ for a short period of time, which significantly speeds up the carbon corrosion.

In phosphoric acid systems, graphitized carbons are the standard because of the need for corrosion resistance in high-temperature acidic environments. In acidic electrolytes the 
mechanism of electrochemical carbon corrosion is generally thought to proceed via a threestep process involving four electrons [22]. The formation of oxygen containing surface groups can be seen as intermediates for oxidation of carbon to carbon dioxide; it has also been mentioned that they build up a protective layer from further oxidation on the carbon [23]. There, Gallagher and Fuller proposed an electrochemical mechanism to predict the formation of $\mathrm{CO}_{2}$ /carbon weight loss and surface oxide growth as a function of time, temperature and potential. They proposed that there is a surface coverage of quinone $\left(\mathrm{C}_{\mathrm{x}}^{\#} \mathrm{O}_{2}\right)$ and/or hydroquinone $\left(\mathrm{C}^{\#}{ }_{\mathrm{x}}(\mathrm{OH})_{2}\right)$ redox couple with a potential of about $550 \mathrm{mV}_{\mathrm{RHE}}$ [20]. This coverage and complex interplay of different surface oxides can significantly affect the equilibrium concentration of catalytic oxide species on the carbon surface. These surface oxides can cause electrical isolation, increased hydrophilicity of the catalyst layer as well as a weakened interaction between carbon support and catalyst particle [24]. The complete oxidation of carbon to $\mathrm{CO}_{2}$ results in loss of active Pt surface, a changed pore structure and morphology of the catalyst layer, including dehydrophobization effects of the remaining catalyst support. This results in voltage losses at higher current densities, most apparently from start-stop degradation or local hydrogen starvation pointing to increased mass transport resistances $[20,25]$. This can be understood by the observation that the associated carbonsupport corrosion leads to cathode thinning, caused by a loss of cathode electrode material and void volume, which in turn increases oxygen diffusion resistances. Yu et al. [10] showed, during corrosion cycles, a thinning of the cathode catalytic layer from about $15 \mu \mathrm{m}$ to $5 \mu \mathrm{m}$, while the membrane and anode catalytic layer thickness remained unchanged. In a worst-case scenario, complete deterioration of the carbon finally would affect the structural integrity of the cathode. Many factors influence the corrosion of carbon in the fuel cell environment such as temperature $[4,14,26]$, potential $[27,28]$, humidity $[19,29]$, structure and surface area of the carbon $[18,24]$. In high temperature PEMFC, a strong adsorption of phosphate anions on platinum is expected to lead to reduction of surface sites for $\mathrm{O}_{2}$ adsorption in intermediate 
potentials (between appr. 300 and $800 \mathrm{mV}_{\mathrm{RHE}}$ ) [34]. Also the limited oxygen solubility in phosphoric acid may lead to additionally reduced performance, as the electrode structure is expected to be changed by carbon corrosion. Moreover, the presence of Pt catalyst may accelerate the rate of carbon corrosion [31].

To determine both potential and start-stop cycle related effects, an experimental study on performance and degradation of a HT-PEMFC short stack has been performed. The 5 cell stack with $163.5 \mathrm{~cm}^{2}$ active area was equipped with BASF P1100W membrane electrode assemblies (MEA). The total operation time was $4,160 \mathrm{~h}$, including more than 1,562 start-stop cycles. A literature survey and first results of this test were published in [30]. Within this publication, a detailed data analysis of cycling experiments as well as additional results on potentiostatic experiments under variation of both cell voltage and temperature including online mass spectroscopy data on carbon corrosion are reported. Each cycle contained 29 minutes of operation at a current density of $0.25 \mathrm{Acm}^{-2}$. One cycle consists of a startup and shutdown event, summing up to 3,124 events. These cycles lead to a degradation rate of less than $26 \mu \mathrm{V}$ cycle $^{-1}$. On the other hand, converting the steady state decay rate of $13.25 \mu \mathrm{V} \mathrm{h}{ }^{-1}$ (a) $0.25 \mathrm{~A} \mathrm{~cm}^{-2}$ (as reported in [30]) to 29 minutes results in an "operation related" decay of $\sim 6.4 \mu \mathrm{V}$ per cycle. This could lead to the conclusion that the remaining $19.6 \mu \mathrm{V}$ has been related due to transient response of start-stop events. A protective startup and shutdown strategy has been developed in order to increase the lifetime of the fuel cell. Then, the stack has been progressively operated according to the protective start-stop algorithms for 1,562 cycles shown in section 3.3. Additionally, we made an attempt to evaluate and predict the lifetime of the stacks based on the results between carbon corrosion tests and simulated startstop events.

\section{Experimental procedure}

This section explains the experimental setup and equipment used for testing the aging of fuel cells. All measurements were carried out in a stack of 5 BASF Celtec ${ }^{\circledR}$ P $1100 \mathrm{~W}$ cells with 
$163.5 \mathrm{~cm}^{2}$ active area using graphite flow field plates. A leakage test using forming gas $(95 \%$ nitrogen, 5\% hydrogen) showed that overall leakage rates for the stack were less than

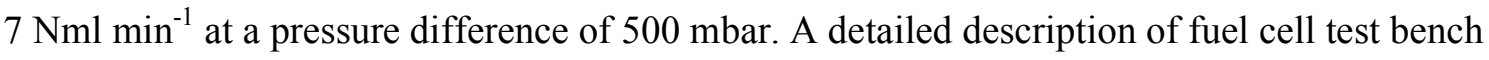
and its accessories are described in the previous literature [30]. In this article, we evaluate the impact of carbon corrosion on a stack level despite of the complexity of the system. The rate of carbon corrosion during transient conditions was determined by the measurement of carbon dioxide released by the fuel cell electrode using mass spectrometry. Additionally, the carbon loading of the MEA was determined ex situ before and after test. Before starting both endurance and cycle tests, a sufficient break in time (continuous run) of $>120 \mathrm{~h}$ at a current density of $0.25 \mathrm{~A} \mathrm{~cm}^{-2}$ was applied. During that time, the cell temperature was kept to $160{ }^{\circ} \mathrm{C}$. During tests, simulated dry reformate $\left(\mathrm{H}_{2} / \mathrm{CO}_{2} / \mathrm{CO} 74.8 / 25 / 0.2\right.$ Volume $\%$ or $\mathrm{H}_{2} / \mathrm{N}_{2} 80 / 20$ Volume \% mixture) was used as anodic fuel at a minimum gas flow rate equivalent to a stoichiometric ratio of 1.25 (anode) and 2.5 (cathode) at a current density of $0.25 \mathrm{~A} \mathrm{~cm}^{-2}$. For the purpose of MEA analysis, one pristine and one tested BASF P 1100W MEA was kept inside distilled water for one day and then had been washed three times with distilled water to remove any remaining phosphoric acid. A section of appr. $10 \mathrm{~cm}^{2}$ of both anode and cathode was removed from the membrane followed by drying in the oven for 3 hours at $120^{\circ} \mathrm{C}$. The samples were weighed and the carbon loading on anode and cathode was determined. An electrode weight (pristine) of $21.3 \mathrm{mg} \mathrm{cm}^{-2}$ (anode) and of $22.0 \mathrm{mg} \mathrm{cm}^{-2}$ (cathode) was measured. Due to the separation performed in advance, no relevant amount of PBI is assumed to be present. Accounting for an assumed Pt loading of $0.5 \mathrm{mg} \mathrm{cm}^{-2}$ (anode) and $1 \mathrm{mg} \mathrm{cm}^{-2}$ (cathode), the $\mathrm{C}$ amount of the electrode (neglecting a small $\mathrm{F}$ fraction attributed to hydrophobizing agents) turns out to be 0.28 moles (anode) and 0.29 moles (cathode) for pristine MEA and 0.253 moles (anode) and 0.2372 moles (cathode) for tested MEAs. The weight loss attributed to the carbon is in principle attributable to all carbonaceous components, including also the bipolar plate. On the other hand, it is very plausible to 
attribute the relative amount of carbon corrosion to be in first order proportional to the specific surface area per geometric area. It becomes obvious, that both catalyst support and -if present- MPL related carbon particles attribute most to the available carbon surface per geometric area. These materials are included in both mass spectrometric and weight related carbon balances. A further hint for exclusion of the bipolar plate from the carbon corrosion balance is that after test no visual change within the flow field could be identified. Summarizing, it is justified to attribute most of the measured corrosion effects to carbon soot particles of catalyst support and MPL particles.

\subsection{Corrosion of carbon and lifetime modelling}

A simple approximation was made to calculate the lifetime of electrode. It is assumed that the end of life is achieved when a significant fraction of the electrode is corroded and discharged as $\mathrm{CO}_{2}$. In reality, the full consumption of the electrode is not possible because the carbon corrosion current goes down with time due to the loss of electrochemical active surface area. The studies of Yu et al $[10,31]$ deduced that potential cycling can cause carbon corrosion and can be assigned to be about $8 \%$ of the total carbon loss for low temperature PEM fuel cells. So, from total electrode corrosion we narrow it down to $20 \%$ loss of carbon from the cathode electrode which could probably give a meaningful value. The usefulness of this value could be confirmed by the experimental data reported below.

The experimental determination of carbon corrosion was performed by potentiostatic experiments under use of mass spectroscopy of cathode inlet and outlet gases. Cell voltages of $650 \mathrm{mV}, 700 \mathrm{mV}$, and OCV at three different cell temperatures were used. Mass spectroscopy data were analysed as follows: Nitrogen is an inert gas and does not participate in the reaction. Since the flow of nitrogen at inlet and outlet are the same, we normalised the cathode outlet molar flow to nitrogen flow rate and determined the corresponding flow rate for carbon dioxide. The difference between measured $\mathrm{CO}_{2}$ concentration at cathode outlet and the 
baseline slope $\mathrm{CO}_{2}$ concentration (out of cathode inlet measurements) provides the amount of corroded carbon. Establishing of a baseline slope is necessary, since air contains appr. 400 ppm carbon dioxide. As a consequence, the translation of the corrosion results should be estimated for time dependent baseline slope given by Eq. (1). This is done to ensure a proper validation of lifetime prediction tool.

Equation for time dependent baseline slope $c\left(\mathrm{CO}_{2}\right)=a+b\left(t-t_{0}\right)$

Where a and $\mathrm{z}$ are $\mathrm{CO}_{2}$ concentrations measured at start $\left(\mathrm{t}_{0}\right)$ and end of cycles $\left(\mathrm{t}_{1}\right)$, and $\mathrm{b}=(\mathrm{z}-$ a) $*\left(\mathrm{t}_{1}-\mathrm{t}_{0}\right)^{-1}$.

Summarizing, the amount of corroded carbon is measured by determination of $\mathrm{CO}_{2}$ exhaust gas concentration using mass spectrometry, offset subtraction according to Eq. (1) and conversion to molar flow rates under use of exhaust gas flow rates obtained from present inlet flow data and correction according to faradaic conversion rates.

The corroded carbon per cycle can be calculated by integrating the molar $\mathrm{CO}_{2}$ flow over time. Finally, the estimated lifetime is assigned to a carbon release of $20 \%$ of the electrode weight.

\section{Results and discussion}

A set of experiments was performed to investigate the rate of carbon support corrosion by applying a potential across the cell and measuring the resulting current while concurrently analysing the cathode exhaust gases with a mass spectrometer.

These experiments were conducted to show the importance of optimisation strategies in order to improve the endurance of the stack life in a Micro CHP system. In order to imitate the real case system, air is used as oxidant throughout the experiment and the measurements were performed without preheating or humidification of reactant gases. The lifetimes predicted should not be taken literally because of remaining uncertainties caused by the necessity to extract the $\mathrm{CO}_{2}$ emissions from the cell in the $400 \mathrm{ppm}$ range out of the difference to a $\mathrm{CO}_{2}$ 
baseline. Nonetheless, the values provided can give semi quantitative information on how the temperature or operating voltage affects the lifetime of such systems.

\subsection{Potential cycling and corrosion of carbon}

A conditioning stage during the start of mass spectrometry is performed for $10 \mathrm{~min}$ at $650 \mathrm{mV}$ single cell voltage average (SCV ave) that ensures stable temperature, pressure and reactants flow rates conditions. On applying load, some time is needed to obtain an equilibrium stage out of production of water, concentration change of phosphoric acid, and small change in carbon dioxide content as well. Due to variation of the cathode potential, we observe oxidation of carbon from the MEA as desorption of carbon dioxide at the cathode outlet which is measured as concentration percentage in the mass spectrometry. In Figure 1 and 2 the carbon dioxide concentration and SCV ave are shown over time for two voltage cycles. The duration of open circuit voltage is $120 \mathrm{~s}$, and for potentials under load state is 180 $\mathrm{s}$, the data acquisition is done for every 7.5 seconds for test bench and mass spectrometry.

A potentiostatic experiment was performed to study the effect of open circuit voltage on corrosion of the carbon by cycling the potentials between $650 \mathrm{mV}, 700 \mathrm{mV}$, and $\mathrm{OCV}$ at three different cell temperatures. In Figure 1, the $\mathrm{CO}_{2}$ release at a cell temperature of $140{ }^{\circ} \mathrm{C}$ is shown under operation for three minutes at $700 \mathrm{mV}$ and $650 \mathrm{mV}$ respectively with intermediate $\mathrm{OCV}$ operation for two minutes. Immediately after switching from OCV to $650 \mathrm{mV}$, an even stronger $\mathrm{CO}_{2}$ release is observed compared to the $\mathrm{CO}_{2}$ peak observed for the switch from OCV to $700 \mathrm{mV}$. As pointed out for LT-PEM fuel cells in [32], we assume that the increased height of $\mathrm{CO}_{2}$ desorption peak at $650 \mathrm{mV}$ compared to the desorption peak at $700 \mathrm{mV}$, indicates that oxidized carbon formed at $\mathrm{OCV}$ is mainly adsorbed at the carbon surface as $\mathrm{C}-\mathrm{O}$, which is oxidized to $\mathrm{CO}_{2}$ according to Eq. (2) due to the release of $\mathrm{OH}_{\mathrm{ad}}$ groups from the Pt catalyst as soon as the potential is reduced to $650 \mathrm{mV}$ :

$$
\mathrm{C}-\mathrm{O}_{\mathrm{ad}}+\mathrm{Pt}-\mathrm{OH}_{\mathrm{ad}} \rightarrow \mathrm{Pt}+\mathrm{CO}_{2}+\mathrm{H}^{+}+\mathrm{e}^{-}
$$


A reduction from $\mathrm{OCV}$ to $700 \mathrm{mV}$ does lead to only fewer corrosion/desorption effects. A second observation is that the $\mathrm{CO}_{2}$ release is decreasing quickly after settling of the potential from $\mathrm{OCV}$ down to $650 \mathrm{mV}$, including an almost baseline $\mathrm{CO}_{2}$ release after a three min stationary potential level of $650 \mathrm{mV}$. Summing up the observations before, we think, that it is possible on a semiquantitative basis to conclude from the desorption peak after reducing the potential down to $650 \mathrm{mV}$ on the accumulated carbon corrosion at higher potentials. Therefore, the investigation was continued with potentiostatic operation keeping $650 \mathrm{mV}$ as reference and cycling between $700 \mathrm{mV}, 750 \mathrm{mV}, 800 \mathrm{mV}, 850 \mathrm{mV}$ also at three different cell temperatures. The idea of this investigation is to evaluate data out of desorptive $\mathrm{CO}_{2}$ release at a cell voltage of $650 \mathrm{mV}$. This cell voltage is selected as reference as it shows full release of desorbed carbon dioxide (within the detectable range of the mass spectrometry). Figure 2 presents the accumulation of $\mathrm{CO}_{2}$ with adsorption desorption effect depending on the potential at $160{ }^{\circ} \mathrm{C}$. We can see that adsorption effect of carbon dioxide strongly increases as we go to higher potentials in the activation region. A similar trend was observed for $120{ }^{\circ} \mathrm{C}$ and $140{ }^{\circ} \mathrm{C}$ cell temperatures. Using these data, including baseline(s) as provided in Figure 2, and media flow rates, the accumulated carbon corrosion per cycle can be calculated. The resulting data are provided in Table 1.

From the data provided in Table 1, it becomes clear, that there is an increase in C corrosion, if the potential is increased from $700 \mathrm{mV}$ to $850 \mathrm{mV}$. A further data analysis has been performed using IR corrected cell voltages, based on a measured average cell resistance of $0.15 \mathrm{Ohm} \mathrm{cm}^{2}$ and current voltage data measured during voltage cycling tests.

The resulting molar corrosion rate vs. IR corrected cell voltages are plotted in Figure 3 a.

In general, the molar corrosion rate follows the exponential tendency, as discussed in the introduction section and expected from literature [16]. Out of the data from the exponential regression provided in Figure 3 a, a slope ranging from $113 \mathrm{mV}$ per decade $\left(120\right.$ and $\left.160{ }^{\circ} \mathrm{C}\right)$ 
to $143 \mathrm{mV}$ per decade $\left(140{ }^{\circ} \mathrm{C}\right)$ can be derived from the data. The slope corresponds to the voltage difference corresponding to an increase in y value $\left(\mathrm{CO}_{2}\right.$ release $)$ by a factor of 10 .

The temperature dependence observed in Figure $3 \mathrm{~b}$ is more complicated and the reasons are not fully clear. For $800 \mathrm{mV}$ and $850 \mathrm{mV}$ cell voltage the corrosion rate follows the general expectations for the temperature, for lower cell voltages a slight decrease of corrosion rate with increasing temperature is observed. Beside some uncertainties out of the measurements, the observed tendency may be explained in part by the fact that the higher current at lower cell potentials leads to a higher water vapor fraction of cathode air and thereby to a significantly lower phosphoric acid concentration which is correlated in literature to increasing carbon corrosion rate [16]. The effect of a higher water vapor fraction is expected due to an increase of water production in combination with a constant gas flow rate during potential cycling experiments. Additional Information on phosphoric acid concentration dependent on temperature and operation conditions is provided in [33].

As described above, lifetime estimations have been derived out of the measured carbon corrosion rates, which are depicted in Figure 4.

It is interesting to notice the opposing trend of carbon corrosion and predicted lifetime over temperature at voltage levels of $700 \mathrm{mV}$ and $750 \mathrm{mV}$. In this potential region, there is a decreasing trend in $\mathrm{CO}_{2}$ production with increasing temperature level. As explained above, this effect may be due to a lower phosphoric acid (PA) concentration at lower temperatures, resulting in higher corrosion rates. For a final confirmation of this result, further measurements are required. On the other hand, for higher potentials $(800 \mathrm{mV}$ and $850 \mathrm{mV})$, the corrosion rate increases with increase in temperature. These voltages correspond to activation region of the characteristic curve, where the presence of potential combined with higher temperature leads to higher corrosion rate.

As a consequence of the results shown, it is better to operate the stack at or below $750 \mathrm{mV}$, as we can see there is an exponential increase of corrosion and corresponding decrease of 
lifetime in the factor of $\sim 6-8$ per $100 \mathrm{mV}$. Therefore operation of the stack extensively at voltages above $750 \mathrm{mV}$ should be avoided to achieve long term endurance and performance.

\subsection{Startup and shutdown strategies}

A series of experiments was performed in order to investigate the effect of startup and shutdown events on carbon support corrosion of the cell. With the help of mass spectrometry carbon dioxide evolution at the cathode side was recorded for two different start and stop sequences at three different cell temperatures $120^{\circ} \mathrm{C}, 140{ }^{\circ} \mathrm{C}$, and $160{ }^{\circ} \mathrm{C}$ respectively. The carbon corrosion rate of the different procedures was investigated by comparing two different start events and two different stop events, one with protection gas $\left(\mathrm{N}_{2}\right)$ and other without protection gas. These procedures normally have two phases of carbon corrosion/desorption: power generation phase and the temperature phase i.e., heatup during start and cooling down the stack during stop. In the following sections, the procedures and corresponding time charts are provided, followed by a discussion section, including analysed $\mathrm{C}$ corrosion induced $\mathrm{CO}_{2}$ release data. The use of a protecting gas during startup and/or shutdown is a common procedure for lab test environments. Since it is often required for systems to operate without protecting gases, the procedures presented have been adopted to such requirements as far as possible without adding additional hardware to the set up. For the cathode side, the adoption was performed by reducing the oxygen content to near zero values by applying a small current under anodic "H2/reformate" and cathodic "no flow" conditions. At the anode side, no such workaround is proposed at this stage, except the recommendation to perform both startup and shutdown at low temperature levels (e.g. $120^{\circ} \mathrm{C}$ ). Also lower temperatures may be permitted, if the anode gas is sufficiently dry to avoid excessive dilution of $\mathrm{H}_{3} \mathrm{PO}_{4}$ during startup or shutdown. Appropriate limits can be derived from data provided in [33]. 


\subsubsection{Start procedure without protecting gas (e Start)}

This simple start procedure can be performed, if the using of protecting gases becomes costly and cumbersome. Here the stack is heated up to the required operating temperature; a sparse air flow of 0.47 SLPM is maintained as carrier gas at cathode for the analysis of carbon dioxide concentration at the cathode outlet. As the desired temperature is reached, fuel and oxidant flow is started to obtain open circuit voltage for 30 seconds. Then, the cell voltage is set to $650 \mathrm{mV}$ (potentiostatic operation) and the current adjusted as such, that a cell voltage of $650 \mathrm{mV}$ is kept. After 5 minutes, the mass spectrometry is shifted to cathode inlet for obtaining the baseline. This procedure is carried out at $160{ }^{\circ} \mathrm{C}, 140{ }^{\circ} \mathrm{C}$ and $120^{\circ} \mathrm{C}$. The startup sequence is shown in the Table 2 and Figure 5 shows a steady increase in carbon dioxide concentration starting from $121^{\circ} \mathrm{C}$ which then peaks up at open circuit voltage.

\subsubsection{Start procedure with protecting gas}

In this experimental procedure, protecting gas nitrogen is used to inert the stack from carbon corrosion. Nitrogen flows through the stack till the operating temperature is reached. Once the temperature is reached first, the fuel flow on the anode side is started, and after $30 \mathrm{sec}$ air is turned on the cathode side. At this stage, a sudden increase in carbon dioxide concentration is observed as shown in Figure 6. The stack is then operated in open circuit voltage for 30 sec. In the next step, $650 \mathrm{mV}$ cell voltage (potentiostatic operation) is set for 300 seconds. After that time, the mass spectrometer is changed again to cathode inlet for drawing the baseline for the analysis of accumulated $\mathrm{CO}_{2}$. This process is repeated for $160{ }^{\circ} \mathrm{C}, 140{ }^{\circ} \mathrm{C}$ and $120{ }^{\circ} \mathrm{C}$. The Table 3 explains the operation sequence of the startup algorithm. 


\subsubsection{Stop procedure without protecting gas (e Stop)}

This shutdown sequence can be done during the times of malfunction or when there is no additional equipment for purging available. In this simple procedure, there is no step of voltage reduction and nitrogen purge included. After the stack has been operated for 5 minutes at current equivalent to $650 \mathrm{mV}$ (potentiostatic operation), current is stopped and anode flow is shut off. This procedure can be considered close to an emergency shutdown procedure, which would also include a cathode air flow shut off. Due to detectability requirements of $\mathrm{CO}_{2}$, a sparse air flow of 0.47 SLPM is maintained to work as carrier gas for the analysis of carbon dioxide concentration at the cathode outlet. Then, the stack is allowed to cool down to $80{ }^{\circ} \mathrm{C}$. In order to ensure reliability of the experiments and for diagnostic purposes, the stack is then inerted by turning on the nitrogen gas on both anode and cathode sides for 5 minutes, followed by switching the mass spectrometric detection to inlet of the stack. This procedure is also done to maintain a proper baseline for the next procedures to be tested at $160{ }^{\circ} \mathrm{C}, 140{ }^{\circ} \mathrm{C}$ and $120^{\circ} \mathrm{C}$.

The Table 4 summarizes the shutdown procedure without protecting gas. The time chart of the corresponding operation (not shown, time dependency of $\mathrm{CO}_{2}$ release comparable to Figure 7) reveals, that the $\mathrm{CO}_{2}$ amount of cathode exhaust gas increases to a maximum value of up to appr. $0.04 \%$ and then gradually decreases almost down to baseline at $100{ }^{\circ} \mathrm{C}$ cell temperature.

\subsubsection{Stop procedure with protecting gas}

After the stack has been operated at $650 \mathrm{mV}$ for $5 \mathrm{~min}$, the current is reduced to $5 \mathrm{~A}$ and the air flow is shut off. In consequence, firstly the current and then the voltage drop to zero. After a minute, the anode flow is switched to nitrogen for one minute and then shut off. The coolant flow is switched off and the stack is allowed to cool down till $80^{\circ} \mathrm{C}$. Then, the stack is made inert by turning on protecting gas $\left(\mathrm{N}_{2}\right)$ on both anode and cathode sides and verified using 
mass spectrometry before stopping the system. The procedure is repeated at $160{ }^{\circ} \mathrm{C}, 140{ }^{\circ} \mathrm{C}$ and $120^{\circ} \mathrm{C}$.

The Table 5 elucidates the shutdown sequence and the Figure 7 demonstrates the operation of the algorithm according to the sequence described above.

\subsubsection{Startup strategies and corrosion of carbon}

In start procedure induced corrosion, it is evident from the Figure 8 that an increase in temperature improves the kinetics of carbon oxidation reaction consequently decreasing the expected lifetime.

In overall the bar graph in the Figure 8 shows the accumulated corroded carbon during start and stop events and its corresponding lifetime for $20 \%$ corrosion of carbon. The start and stop sequences with protecting gas nitrogen is denoted as start 1 and stop 1; and sequences without protecting gas is denoted as e start and e stop.

In startup procedure 1, the stack was made inert by flowing nitrogen through the stack during heat up, which suppresses the carbon oxidation reaction. The $\mathrm{CO}_{2}$ released during power generation phase and its corresponding predicted lifetime, which are plotted as the bar chart in Figure 8, are tabulated in the Table 6 .

The assignment of molar $\mathrm{CO}_{2}$ release data should be understood time wise and not necessarily status wise, since the $\mathrm{CO}_{2}$ desorption is (as discussed above) strongly dependent e.g. on electrode potentials. Nonetheless, it is expected, that the total $\mathrm{CO}_{2}$ release observed is in good correlation with the carbon corrosion within the processes discussed.

In the case of simplified startup, there is no protecting gas during heat up, so the degradation starts before the flow of reactants. There is no or very negligible amount of $\mathrm{CO}_{2}$ desorption for $120^{\circ} \mathrm{C}$ in startup phase, nevertheless produces $19.7 \mu$ moles during power generation 
phase. In $140{ }^{\circ} \mathrm{C}$ startup, we can see that the start of $\mathrm{CO}_{2}$ desorption starts around $121^{\circ} \mathrm{C}$ and there is $2.3 \mu$ moles of $\mathrm{CO}_{2}$. The carbon corrosion on applying load accounts to $30.2 \mu$ moles. Similarly at $160{ }^{\circ} \mathrm{C}$ Startup yields $3.6 \mu$ moles during heating phase and $38.1 \mu$ moles in power generation phase, which results in total to $41.2 \mu$ moles.

In overall, the startup procedure with protecting gas has less corrosion than e-start. When we compare between temperatures, we see that there is less difference between e-start and start 1 at $120^{\circ} \mathrm{C}$. Additionally we also noticed that from Figure 5, the visible corrosion of carbon starts above $120{ }^{\circ} \mathrm{C}$. Since the observed $\mathrm{CO}_{2}$ release is continuously increasing above $120{ }^{\circ} \mathrm{C}$, it would be optimal to adopt start power generation around $110-120{ }^{\circ} \mathrm{C}$ to achieve longer lifetime.

\subsubsection{Shutdown strategies and corrosion of carbon}

The carbon corrosion rate of the different procedures was investigated by comparing three stop cycles with each other at the three different temperatures:

Three different stop algorithms were planned for investigation of carbon corrosion rate at three different temperatures; with protecting gas on anode side, with protecting gas on both sides and an emergency stop without nitrogen. A stop sequence with protecting gas on both sides could not be tested due to test bench reasons.

The moles of $\mathrm{CO}_{2}$ for the stop algorithm corresponding to operation phase and cool down phase is given in the Table 7.

Similar to the start events, we observe the decreasing trend of carbon dioxide evolution as we go down with temperature. During the cool down phase, more carbon dioxide is produced than during the operation (power generation) phase. This means an active cooling strategy should be performed with an increased temperature decay rate, thereby reducing the degradation of the cell during this phase. It must be also noted that there was no active 
cooling circuit employed during these experiments. The stop procedure with protecting gas at the anode side and a reduction of oxygen content by applying an electric current at the cathode side has shown to cause a lower degradation than e-Stop without use of protecting gases.

\subsection{Long term testing of start-stop cycles and lifetime analysis}

Start procedure 1 with protecting gas on both sides at $120^{\circ} \mathrm{C}$ is selected as it has the least degrading effect and $160{ }^{\circ} \mathrm{C}$ is selected for stop procedure 1 with protecting gas as there is no cooling loop in the test bench and it is also closer to the temperature that can be realised in the system level. These algorithms are based on the procedures described above under use of protecting gas and were slightly modified by a change from voltage control at $650 \mathrm{mV}$ average single cell voltage to an approximately equivalent current control $\left(0.25 \mathrm{~A} \mathrm{~cm}^{-2}\right)$, which is easier to be implemented and lead to a similar voltage level. For the test of long term endurance anodic flow is switched to simulated reformate $\left(74.8 \% \mathrm{H}_{2}, 25 \% \mathrm{CO}_{2}, 0.2 \% \mathrm{CO}\right)$ operation as it is sufficiently close to fuels which are generally used in CHP application. These sequences were implemented as an automatic routine within the PLC control unit of the test bench. The Table 8 and Table 9 show the modified startup and shutdown sequences. The figures of the algorithm and the corresponding study of performance and voltage degradation of the stack under this operation regime has been reported [30].

The stack is operated for 4,160 hours, including 4,042 hours of start- stop cycling ( 1,562 cycles in total) with 430.6 hours ( 170 cycles) under hydrogen nitrogen mixture and 3,612 hours (1,392 cycles) under simulated reformate. Out of 170 cycles, 5 initial cycles (26) and 5 cycles (from 1,094 - 1,098) under operation of hydrogen nitrogen mixture were evaluated for carbon dioxide evolution at the cathode outlet of the fuel cell stack. After the endurance test the MEA's are weighed for carbon loading as described in section 2.1. The 
carbon loading on the new electrodes and carbon of the tested electrodes are provided in Table 10.

The lifetime predicted for the measured $18.2 \%$ loss of carbon was found for regular cycles at different times are shown in Table 11.

Table 11 reveals an interesting fact that during initial cycles the estimated life time (in cycles) predicted for loss of carbon is 2,225 , whereas after 1,088 cycles the predicted life time amounts to 950 cycles. The total amount of carbon corroded for 10 start-stop cycles was predicted as 1,621 cycles whereas experimental life time amounts to 1,562 cycles. This shows that lifetime prediction by this method shows a good accuracy compared to performance data provided in [30]. Emergency shutdowns were performed due test bench reasons after 1,264 h and $4,110 \mathrm{~h}$ of operation might have effected in additional carbon corrosion as well as the polarization curves performed after $9,463,1,289$ and 1,562 cycles of start-stop.

\section{Conclusions}

In this paper we have investigated the rate of carbon corrosion during transient conditions, by the measurement of carbon dioxide released by the fuel cell electrode using on-line mass spectrometry. The impact of carbon corrosion has been studied on high temperature fuel cell stack based on $\mathrm{PBI} / \mathrm{H}_{3} \mathrm{PO}_{4}$ in accelerated degradation tests employing increased cell voltages with different methods for quantifying the carbon corrosion and characterizing the effect of it. Potential cycling has been performed in a fuel cell stack at different operating temperatures with online measurement of carbon corrosion using mass spectrometry. We observed that operation of high temperature PEM fuel cells at OCV has a severe negative impact on both fuel cell durability and performance. Extended operation of the stack in the activation region $(>750 \mathrm{mV})$ accelerates degradation exponentially with a slope ranging from 113 to $143 \mathrm{mV}$ per decade and should be avoided to prolong the life of the fuel cells. Based on the 
findings, a protective startup and shutdown strategy has been designed in order to increase the lifetime of the fuel cell. These start and stop algorithms were then adopted to a test bench environment and performed at different operating temperatures. The MEA long-term stability of more than 1,562 cycles $(3,124$ start and shutdown events) with a degradation rate of less than $26 \mu \mathrm{V} \mathrm{cycle}^{-1}$ at $0.25 \mathrm{~A} \mathrm{~cm}^{-2}$ showing less than $20 \%$ mass loss at the electrodes had been demonstrated. Subtracting the corresponding decay rate for stationary operation of $6.4 \mu \mathrm{V}$ cycle $^{-1}\left(13.3 \mu \mathrm{Vh}^{-1}\right.$ as reported in [30]), we obtain an attractable low degradation of only 19.6 $\mu \mathrm{V}$ cycle $^{-1}$; which can be further reduced significantly by avoiding OCV. The observed total cathode electrode mass loss after test turned out to be in good agreement to predicted data determined from on line mass spectroscopy of released $\mathrm{CO}_{2}$ in selected stop start cycles. Summarizing, the model for lifetime prediction based on quantification of the $\mathrm{CO}_{2}$ evolution on start-stop cycles has been confirmed with good agreement to performance data demonstrating the high value of the experimental approach and proposed analysis method. Being aware that degradation process of HT-PEMFC are based on many effects (e.g. carbon corrosion, Pt surface area loss with different mechanisms, but also including loss of catalyst support, dehydrophobization), we consider the measurement of carbon corrosion rate as a good approach for obtaining accelerated "overall" degradation data within the HT-PEMFC application field.

\section{Acknowledgement}

This work was partially supported by the Ministerium für Wissenschaft, Forschung und Kunst Baden-Württemberg (Capital 1223 Title group 91). We thank the fuel cell team at ZSW for assistance in stack and test bench hardware. 


\section{References}

[1] DOE Fuel Cell Technologies Office Multi-Year Research, Development, and Demonstration Plan, Section 3.4, updated 2016, available via https://energy.gov/eere/fuelcells/downloads/fuel-cell-technologies-office-multi-yearresearch-development-and-22 (July 2017)

[2] C. Hartnig, T.J. Schmidt, J. Power Sources 2011, 196, 5564-5572.

[3] C. Reiser, L.J. Bregoli, T.W. Patterson, J.S. Yi, J.D. Yang, M.L. Perry, and T.D. Jarvi, Electrochem. Sol. Lett. 2005, 8 (6), A273-A276.

[4] F. N. Buchi, M. Inaba, T.J. Schmidt, Polymer Electrolyte Fuel Cell Durability Springer, NY, 2009

[5] H. Tang, Z. Qi, M. Ramani, and J. F. Elter, J. Power Sources 2006,158 (2), 1306-1312.

[6] A. Taniguchi, T. Akita, K. Yasuda, and Y. Miyazaki, J. Power Sources 2004, 130, 4249.

[7] H. Chizawa, Y. Ogami, H. Naka, A. Matsunaga, N. Aoki, and T. Aoki, ECS Transactions, 3, (2006) 645-655.

[8] H. Chizawa, Y. Ogami, H. Naka, A. Matsunaga, N. Aoki, T. Aoki, and K. Tanaka, ECS Transactions 2007, 11, 981-992.

[9] S. D. Knights, K. M. Colbow, J. St-Pierre, and D. P. Wilkinson, J. Power Sources 2004, 127, 127-134.

[10] M.F. Mathias, R. Makharia, H. Gasteiger, J.J. Conley, T.J. Fuller, G.J. Gittleman, S.S. Kocha, D.P. Miller, C.K. Mittelsteadt, T. Xie, S.G. Yan, P.T. Yu, Interface 2005, 14, $24-35$.

[11] J.C. Meier, C. Galeano, I. Katsounaros, A.A. Topalov, A. Kostka, F. Schueth, K.J.J. Mayrhofer, ACS Catalysis 2012, 2, 832-843.

[12] H. Schulenburg, B. Schwanitz, J. Krbanjevic, N. Linse, G.G. Scherer, A. Wokaun, Electrochemistry Communications 2011, 13, 921-923.

[13] F. Ettingshausen, J. Kleemann, A. Marcu, G. Toth, H. Fuess, C. Roth, Fuel Cells 2011, $11,238-245$.

[14] Q. Li, D. Aili, H.A. Hjuler, J.O. Jensen, High Temperature Polymer Electrolyte Membrane Fuel Cells: Approaches, Status and Perspectives, Springer, NY, 2015

[15] K. Kinoshita, and J. Bett, Carbon 1973, 11, 237

[16] K. Kinoshita, Carbon. Electrochemical and Physicochemical Properties, Wiley, NY, 1988, 328-34

[17] R. M. Darling, J. P. Meyers, J. Electrochemical Society 2003, 150 (11), A1523A1527. 
[18] R. Borup, et al., Chemical Reviews 2007, 107, 3904-3951.

[19] P. L. Antonucci, F. Romeo, M. Minutoli, E. Alderucci, and N. Giordano, Carbon 1988, 26 (2), 197-203.

[20] K.H. Kangasniemi, D.A. Condit, T.D. Jarvi, J. Electrochemical Soc. 2004, 151 (4), 125.

[21] A. P. Young, et al. J. Electrochemical Society 2009 156(8), B913-B922.

[22] L.M. Roen, C.H. Paik, T.D. Jarvi, Electrochemical Solid-State Letters 2004, 7(1), A19.

[23] K. G. Gallagher, D. T. Wong, and T. F. Fuller, J. Electrochemical Society 2008, 155, B488-B493.

[24] Y. Shao, G. Yin, and Y. Gao, J. Power Sources 2007, 171, 558-566.

[25] C. He, S. Desai, G. Brown, and S. Bollepalli, Electrochemical Society Interface 2005, $14,41-44$.

[26] Y. Oono, T. Fukuda, A. Sounai and M. Hori, J. Power Sources 2010, 195 (4), $1007-$ 1014.

[27] Z. Qi, S. Buelte, J. Power Sources 2006, 161, 1126-1132.

[28] P. J. Ferreira, R. Makharia, S. Kocha, H.A. Gasteiger, J. Electrochemical Society 2005, 152 (11), A2256-A2271

[29] P. Stonehart, Carbon 1984, 22(4/5), 423-431.

[30] A. Kannan, A. Kabza, J. Scholta. J. Power Sources 2015, 277, 312-316.

[31] P.T. Yu, Z. Liu, R. Makharia, J. Electrochem. Soc. 2013, 160, F645-F650.

[32] S. Mass, F. Finsterwalder, G. Frank, R. Hartmann, C. Merten, J. of Power Sources 2008, 176, 444-451

[33] R. Kuhn, J. Scholta, Ph. Krüger, Ch. Hartnig, W. Lehnert, T. Arlt, I. Manke, Journal of Power Sources 2011, 196, 5231-5239.

[34] S. Kaserer, K. M. Caldwell, D. E. Ramaker, C. Roth, The Journal of Physical Chemistry C 2013, 117(12), 6210-6217. 


\section{Tables}

Table 1: $\mathrm{CO}_{2}$ release dependent on cell potential and temperature

\begin{tabular}{|c|c|c|c|c|}
\hline \multicolumn{5}{|c|}{$\mathrm{CO}_{2}$ release $/ \mu$ mole cycle $^{-1}$} \\
\hline $\begin{array}{c}\text { IR-corrected } \\
\text { cell voltage }\end{array}$ & Cell voltage & \multicolumn{3}{|c|}{ Temperature } \\
\cline { 3 - 5 } & & $120^{\circ} \mathrm{C}$ & $140^{\circ} \mathrm{C}$ & $160^{\circ} \mathrm{C}$ \\
\hline $851 \mathrm{mV}$ & $850 \mathrm{mV}$ & 2.02 & 2.28 & 3.45 \\
\hline $802 \mathrm{mV}$ & $800 \mathrm{mV}$ & 1.31 & 1.86 & 2.19 \\
\hline $755 \mathrm{mV}$ & $750 \mathrm{mV}$ & 0.56 & 0.50 & 0.44 \\
\hline $710 \mathrm{mV}$ & $700 \mathrm{mV}$ & 0.33 & 0.28 & 0.24 \\
\hline
\end{tabular}

Table 2: $\quad$ Startup sequence without protecting gas

\begin{tabular}{|c|c|c|c|c|}
\hline e Start & Step 1 & Step 2 & Step 3 & Step 4 \\
\hline & heat up & $\begin{array}{c}\text { Switch at } \\
\mathrm{T}=120^{\circ} \mathrm{C}, \\
140^{\circ} \mathrm{C}, 160^{\circ} \mathrm{C}\end{array}$ & $50 \mathrm{sec}$ & $300 \mathrm{sec}$ \\
\hline Current & & $\begin{array}{l}\text { No current, cell } \\
\text { open }\end{array}$ & $\begin{array}{l}\text { Set to } 650 \\
\mathrm{mV}\end{array}$ & Set to650 mV \\
\hline Anode & Air (ambient) & Fuel flow & Fuel flow & Fuel flow \\
\hline Cathode & Sparse Air flow & Air flow & Air flow & Air flow \\
\hline Operation & No $\mathrm{N}_{2}$ Purging & Temp - OCV & $\begin{array}{c}\text { Operation at } \\
650 \mathrm{mV}\end{array}$ & $\begin{array}{c}\text { Analysis of } \\
\text { accumulated } \mathrm{CO}_{2}\end{array}$ \\
\hline
\end{tabular}

Table 3: Startup sequence with protecting gas

\begin{tabular}{|c|c|c|c|c|c|}
\hline Start 1 & Step 1 & Step 2 & Step 3 & Step 4 & Step 5 \\
\hline & heat up & $\begin{array}{c}\text { Switch at } \\
120^{\circ} \mathrm{C}, \\
140^{\circ} \mathrm{C}, 160^{\circ} \mathrm{C}\end{array}$ & $30 \mathrm{sec}$ & $50 \mathrm{sec}$ & $\mathbf{3 0 0 ~ s e c}$ \\
\hline
\end{tabular}




\begin{tabular}{|c|c|c|c|c|}
\hline e Stop & Step 1 & Step 2 & Step 3 & Step 4 \\
\hline & $-300 \mathrm{Sec}$ & $0 \mathrm{Sec}$ & $80^{\circ} \mathrm{C}$ & $300 \mathrm{Sec}$ \\
\hline Current & $\begin{array}{c}\text { Current@ } \\
650 \mathrm{mV}\end{array}$ & $\begin{array}{c}\text { No } \\
\text { current, } \\
\text { cell open }\end{array}$ & & $\begin{array}{c}\text { Stop } \\
\text { system }\end{array}$ \\
\hline Anode & Fuel flow & $\begin{array}{l}\text { Stop gas } \\
\text { flow }\end{array}$ & $\mathrm{N}_{2}$ flow & \\
\hline Cathode & Air flow & $\begin{array}{c}\text { Sparse air } \\
\text { flow }\end{array}$ & $\mathrm{N}_{2}$ flow & \\
\hline Operation & $\begin{array}{l}650 \mathrm{mV} \\
\text { current }\end{array}$ & cool down & $\begin{array}{c}\text { Analysis of } \\
\text { accumulated } \\
\mathrm{CO}_{2}\end{array}$ & $\begin{array}{c}\text { Cathode } \\
\text { inlet }\end{array}$ \\
\hline
\end{tabular}

\begin{tabular}{|c|c|c|c|c|c|}
\hline Current & & & $\begin{array}{c}\text { No current, } \\
\text { cell open }\end{array}$ & $\begin{array}{c}\text { Set to } 650 \\
\mathrm{mV}\end{array}$ & Set to $650 \mathrm{mV}$ \\
\hline Anode & $\mathrm{N}_{2}$ flow & Fuel flow & Fuel flow & Fuel flow & Fuel flow \\
\hline Cathode & $\mathrm{N}_{2}$ flow & $\mathrm{N}_{2}$ flow & Air flow & Air flow & Air flow \\
\hline Operation & $N_{2}$ Purge & Temperature & OCV & $\begin{array}{c}\text { Operation } \\
\text { at } 650 \mathrm{~m} V\end{array}$ & $\begin{array}{c}\text { Analysis of } \\
\text { accumulated CO }\end{array}$ \\
\hline
\end{tabular}

Table 4: Stop sequence without protecting gas (use of $\mathrm{N}_{2}$ purge only for $\mathrm{CO}_{2}$ detection)

Table 5: Shutdown sequence with protecting gas at anode

\begin{tabular}{|c|c|c|c|c|c|c|}
\hline Stop 1 & Step 1 & Step 2 & Step 3 & Step 4 & Step 5 & Step 6 \\
\hline & $-300 \mathrm{Sec}$ & $0 \mathrm{Sec}$ & $60 \mathrm{Sec}$ & $120 \mathrm{Sec}$ & $80^{\circ} \mathrm{C}$ & $300 \mathrm{Sec}$ \\
\hline Current & $\begin{array}{c}\text { Current@ } \\
650 \mathrm{mV}\end{array}$ & 5 Amps & $\begin{array}{c}\text { No current, } \\
\text { cell open }\end{array}$ & & & $\begin{array}{c}\text { Stop } \\
\text { system }\end{array}$ \\
\hline Anode & Fuel flow & Fuel flow & $\begin{array}{l}\text { Switch to } \\
\text { nitrogen }\end{array}$ & $\begin{array}{l}\text { Stop gas } \\
\text { flow }\end{array}$ & $\mathrm{N}_{2}$ flow & \\
\hline
\end{tabular}




\begin{tabular}{|c|c|c|c|c|c|c|}
\hline Cathode & Air flow & $\begin{array}{c}\text { Stop air } \\
\text { flow }\end{array}$ & & $\mathrm{N}_{2}$ flow & \\
\hline Operation & $\begin{array}{c}\mathbf{6 5 0} \mathbf{m} \boldsymbol{V} \\
\text { current }\end{array}$ & $\begin{array}{c}\text { Voltage } \\
\text { reduction }\end{array}$ & $\mathrm{N}_{2}$ Purge & $\begin{array}{c}\text { cool } \\
\text { down }\end{array}$ & $\begin{array}{c}\text { Analysis of } \\
\text { accumulated } \\
\boldsymbol{C O}_{2}\end{array}$ & $\begin{array}{c}\text { Cathode } \\
\text { inlet }\end{array}$ \\
\hline
\end{tabular}

Table 6: Startup induced Corrosion

\begin{tabular}{|c|c|c|c|}
\hline Startup & \multicolumn{3}{|c|}{$\mathrm{CO}_{2} / \mu$ moles per start event } \\
\hline Start 1 & $120{ }^{\circ} \mathrm{C}$ & $140{ }^{\circ} \mathrm{C}$ & $160{ }^{\circ} \mathrm{C}$ \\
\hline Heat up & - & - & - \\
\hline Operation & 18.0 & 27.9 & 32.1 \\
\hline Total & $\mathbf{1 8 . 0}$ & $\mathbf{2 7 . 9}$ & $\mathbf{3 2 . 1}$ \\
\hline e Start & & & \\
\hline Heat up & - & 2.34 & 3.59 \\
\hline Operation & 19.7 & 30.2 & 38.1 \\
\hline Total & $\mathbf{1 9 . 7}$ & $\mathbf{3 2 . 6}$ & $\mathbf{4 1 . 7}$ \\
\hline \multicolumn{4}{|r}{} \\
\hline
\end{tabular}

Table 7: Shutdown induced Corrosion

\begin{tabular}{|c|c|c|c|}
\hline Shutdown & \multicolumn{3}{|c|}{$\mathrm{CO}_{2} / \mu$ moles per stop event } \\
\hline Stop 1 & $120{ }^{\circ} \mathrm{C}$ & $140{ }^{\circ} \mathrm{C}$ & $160{ }^{\circ} \mathrm{C}$ \\
\hline Operation & 2.8 & 3.36 & 4.33 \\
\hline Cool down & 3.74 & 6.15 & 12.3 \\
\hline Total & $\mathbf{6 . 5 4}$ & $\mathbf{9 . 5 1}$ & $\mathbf{1 6 . 6}$ \\
\hline eStop & & & \\
\hline Operation & 3.30 & 3.52 & 3.71 \\
\hline Cool down & 7.71 & 16.4 & 25.0 \\
\hline Total & $\mathbf{1 1 . 0}$ & $\mathbf{1 9 . 9}$ & $\mathbf{2 8 . 7}$ \\
\hline
\end{tabular}

Table 8: Modified Startup Sequence

\begin{tabular}{|c|c|c|c|c|c|}
\hline Start & Step 1 & Step 2 & Step 3 & Step 4 & Step 5 \\
\hline Time & $0 \mathrm{sec}$ & $30 \mathrm{sec}$ & $30 \mathrm{sec}$ & $90 \mathrm{sec}$ & $\sim 820 \mathrm{sec}$ \\
\hline Current & & & $\begin{array}{l}\text { No current, } \\
\text { cell open }\end{array}$ & $\begin{array}{c}\text { Ramp up to } \\
40,5 \mathrm{~A}\end{array}$ & $40,5 \mathrm{~A}$ \\
\hline Anode & $\begin{array}{c}\text { Protection } \\
\text { gas }\end{array}$ & $\begin{array}{l}\text { Reformate } \\
\text { flow }\end{array}$ & $\begin{array}{l}\text { Reformate } \\
\text { flow }\end{array}$ & $\begin{array}{l}\text { Reformate } \\
\text { flow }\end{array}$ & $\begin{array}{l}\text { Reformate } \\
\text { flow }\end{array}$ \\
\hline
\end{tabular}


Table 9: Modified Shutdown Sequence

\begin{tabular}{|c|c|c|c|c|c|}
\hline Stop & Step 6 & Step 7 & Step 8 & Step 9 & Step 10 \\
\hline Time & $900 \mathrm{sec}$ & $600 \mathrm{sec}$ & $60 \mathrm{sec}$ & $60 \mathrm{sec}$ & Stop \\
\hline Current & $40,5 \mathrm{~A}$ & $5 \mathrm{~A}$ & $5 \mathrm{~A}$ & $\begin{array}{l}\text { No current, } \\
\text { cell open }\end{array}$ & \\
\hline Anode & $\begin{array}{l}\text { Reformate } \\
\text { flow }\end{array}$ & $\begin{array}{c}\text { Reformate } \\
\text { flow }\end{array}$ & $\begin{array}{l}\text { Reformate } \\
\text { flow }\end{array}$ & $\begin{array}{l}\text { Protection } \\
\text { gas }\end{array}$ & $\begin{array}{c}\text { Protection } \\
\text { gas }\end{array}$ \\
\hline Cathode & Air flow & Air flow & No flow & No flow & No flow \\
\hline Temperature & & & & $\begin{array}{l}\text { Oil Pump } \\
\text { off }\end{array}$ & Stack $80^{\circ} \mathrm{C}$ \\
\hline Operation & $40.5 \mathrm{~A}$ & $5 \mathrm{~A}$ & $\begin{array}{l}\text { Voltage } \\
\text { reduction }\end{array}$ & $\begin{array}{l}\text { Protecting } \\
\text { gas purge }\end{array}$ & cool down \\
\hline
\end{tabular}

Table 10: Weight measurements of new and tested electrode

\begin{tabular}{|c|c|c|c|c|c|}
\hline & \multicolumn{2}{|c|}{ Fresh MEA } & \multicolumn{2}{c|}{ After Cycling } & \\
\hline Electrode & $\begin{array}{c}\text { Weight / } \\
\text { (mg/electrode) }\end{array}$ & $\begin{array}{c}\text { Weight / } \\
\text { moles }\end{array}$ & $\begin{array}{c}\text { Weight / } \\
\text { (mg/electrode) }\end{array}$ & $\begin{array}{c}\text { Weight / } \\
\text { moles }\end{array}$ & $\begin{array}{c}\text { carbon loss / } \\
\%\end{array}$ \\
\hline Cathode & 3478.42 & 0.29 & 2846.37 & 0.2372 & 18.18 \\
\hline Anode & 3582.74 & 0.3 & 3036.52 & 0.253 & 15.26 \\
\hline
\end{tabular}


Table 11: Lifetime evaluation based on carbon loss and carbon corrosion measurements

\begin{tabular}{|c|c|c|c|}
\hline Cycles & $\begin{array}{c}\text { Accumulated } \\
\text { corroded carbon / } \\
\text { moles }\end{array}$ & $\begin{array}{c}\text { Estimated time for full } \\
\text { corrosion of carbon / } \\
\text { cycles }\end{array}$ & $\begin{array}{l}\text { Lifetime predicted for 18.18 } \\
\text { \% carbon loss / cycles }\end{array}$ \\
\hline $2-6$ & $5.92 \mathrm{E}-04$ & 12240 & 2225 \\
\hline $1094-1098$ & $1.03 \mathrm{E}-03$ & 7012 & 1275 \\
\hline For 10 cycles & $1.63 \mathrm{E}-03$ & 8916 & 1621 \\
\hline
\end{tabular}

15

16

17

18

19

20

21

22

23

24

25

26

27

28

29

30

31

32

33

34

35

36

37

38

39

40

41

42

43

44

45

46

47

48

49

50

51

52

53

54

55

56

57

58

59

60 


\section{Figure legends}

Figure 1: Measured $\mathrm{CO}_{2}$ response as a function of average single cell voltage: a) Effect of $\mathrm{OCV}$ at $140{ }^{\circ} \mathrm{C}$, Solid line indicates $\mathrm{CO}_{2}$ response and its baseline; dashed line indicates voltage

Figure 2: Measured $\mathrm{CO}_{2}$ response as a function of average single cell voltage: Impact of potentials at $160{ }^{\circ} \mathrm{C}$; Solid line indicates $\mathrm{CO}_{2}$ response and its baseline; dashed line indicates voltage

Figure 3: Molar $\mathrm{CO}_{2}$ release per cycle dependent on (a) IR-corrected cell potential (b) cell temperature

Figure 4: Accumulated corroded carbon per cycle and its corresponding prediction of lifetime as a function of temperature and voltage: Impact of Potentials; Weave pattern indicates accumulated corroded carbon and its corresponding lifetime for $20 \%$ corrosion of carbon indicated as solid pattern.

Figure 5: Start procedure without protecting gas at $140{ }^{\circ} \mathrm{C}$

Figure 6: Start procedure with protecting gas at $120^{\circ} \mathrm{C}$

Figure 7: Stop procedure with protecting gas at $140{ }^{\circ} \mathrm{C}$

Figure 8: Accumulated corroded carbon for startup and shutdown events and its corresponding prediction of lifetime (numbers of start resp. stop events for $20 \%$ corrosion of carbon) as a function of temperature. 
Figure 1: Measured $\mathrm{CO}_{2}$ response as a function of average single cell voltage: a) Effect of $\mathrm{OCV}$ at $140{ }^{\circ} \mathrm{C}$, Solid line indicates $\mathrm{CO}_{2}$ response and its baseline; dashed line indicates voltage 
Figure 2: Measured $\mathrm{CO}_{2}$ response as a function of average single cell voltage: Impact of potentials at 160 ${ }^{\circ} \mathrm{C}$; Solid line indicates $\mathrm{CO}_{2}$ response and its baseline; dashed line indicates voltage 


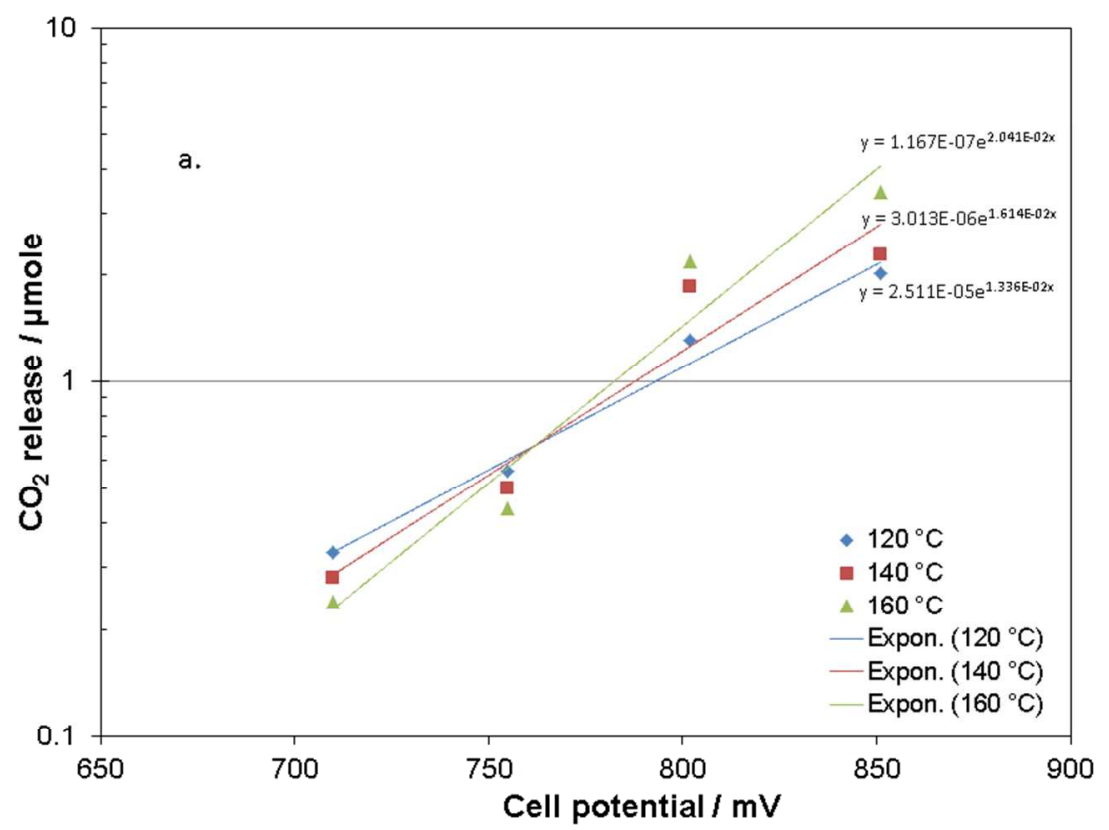

Figure 3: Molar $\mathrm{CO}_{2}$ release per cycle dependent on (a) IR-corrected cell potential (b) cell temperature 
1

2

3

4

5

6

7

8

9

10

11

12

13

14

15

16

17

18

19

20

21

22

23

24

25

26

27

28

29

30

31

32

33

34

35

36

37

38

39

40

41

42

43

44

45

46

47

48

49

50

51

52

53

54

55

56

57

58

59

60

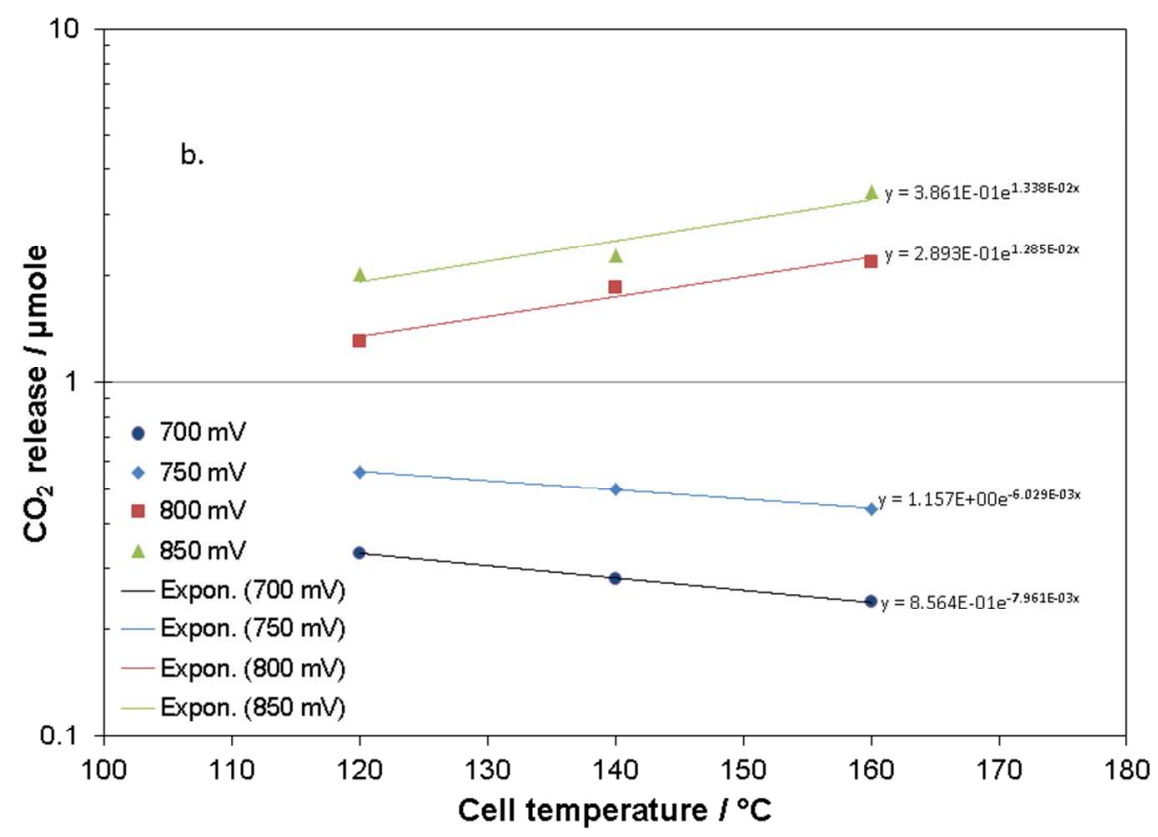

Figure 3: Molar $\mathrm{CO}_{2}$ release per cycle dependent on (a) IR-corrected cell potential (b) cell temperature 
Figure 4: Accumulated corroded carbon per cycle and its corresponding prediction of lifetime as a function of temperature and voltage: Impact of Potentials; Weave pattern indicates accumulated corroded carbon and its corresponding lifetime for $20 \%$ corrosion of carbon indicated as solid pattern.

\section{$120 \times 80 \mathrm{~mm}(300 \times 300 \mathrm{DPI})$}



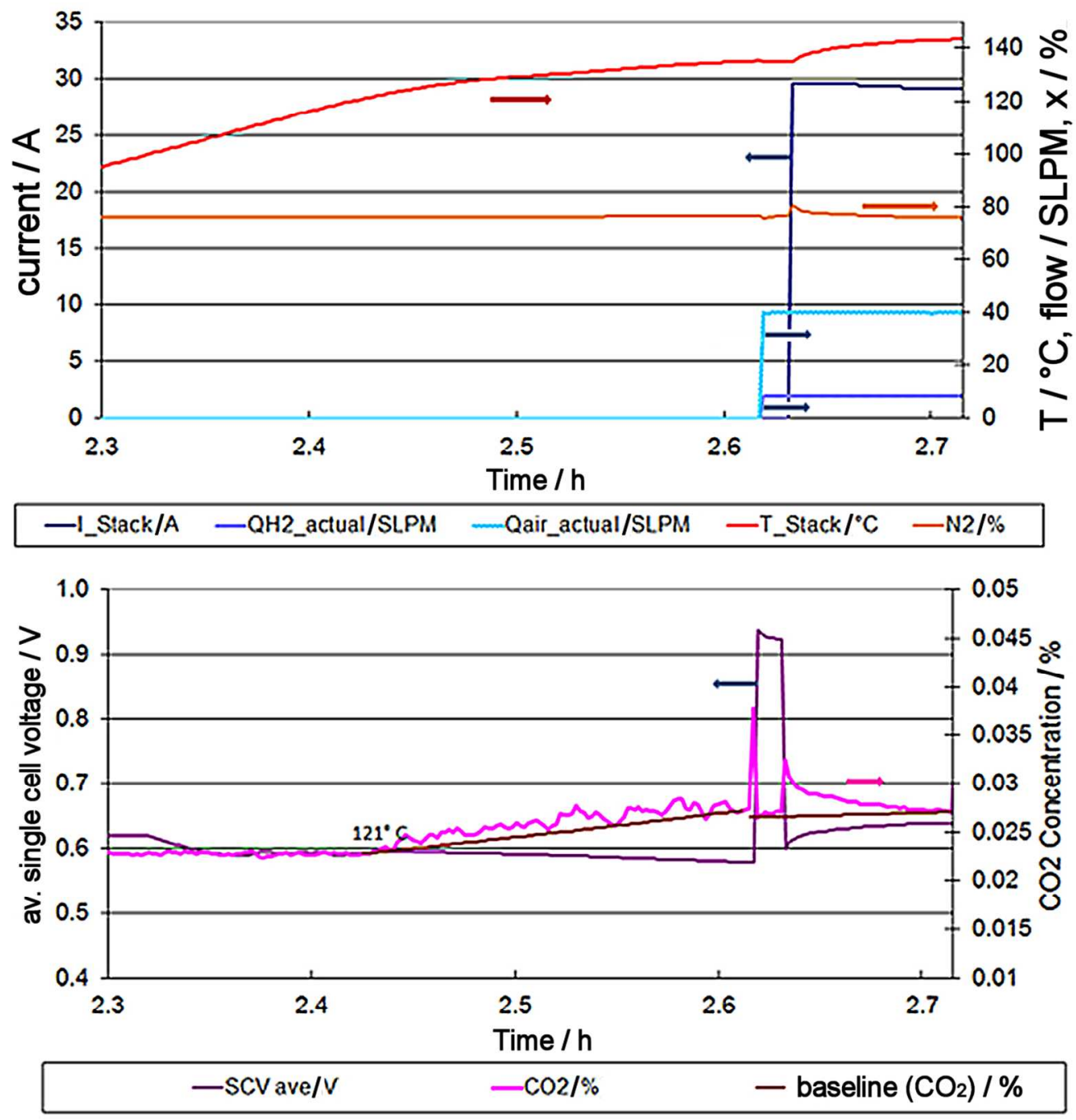

Figure 5: Start procedure without protecting gas at $140^{\circ} \mathrm{C}$

$119 \times 124 \mathrm{~mm}(300 \times 300$ DPI $)$ 

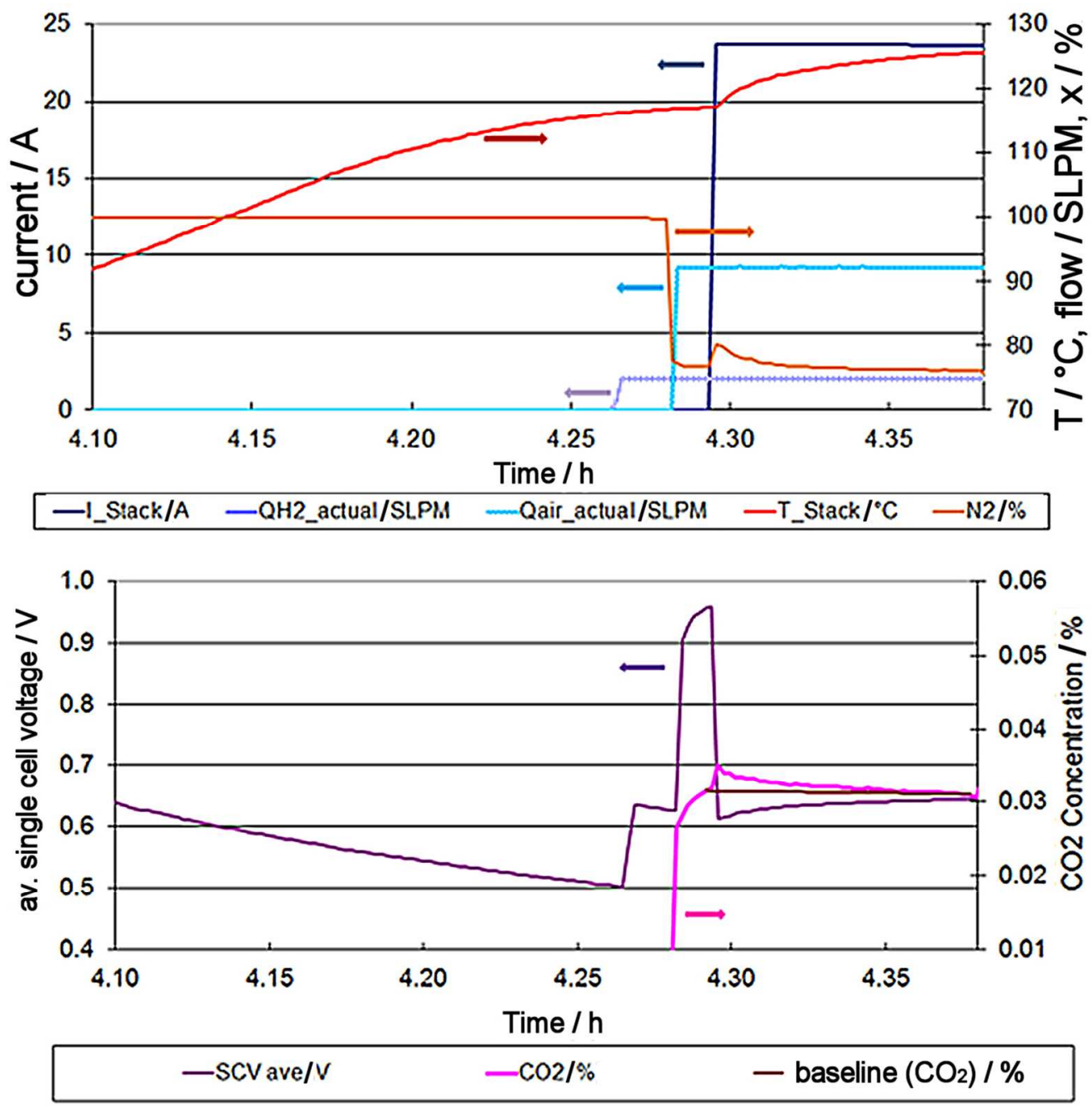

Figure 6: Start procedure with protecting gas at $120^{\circ} \mathrm{C}$

$119 \times 122 \mathrm{~mm}(300 \times 300$ DPI $)$ 


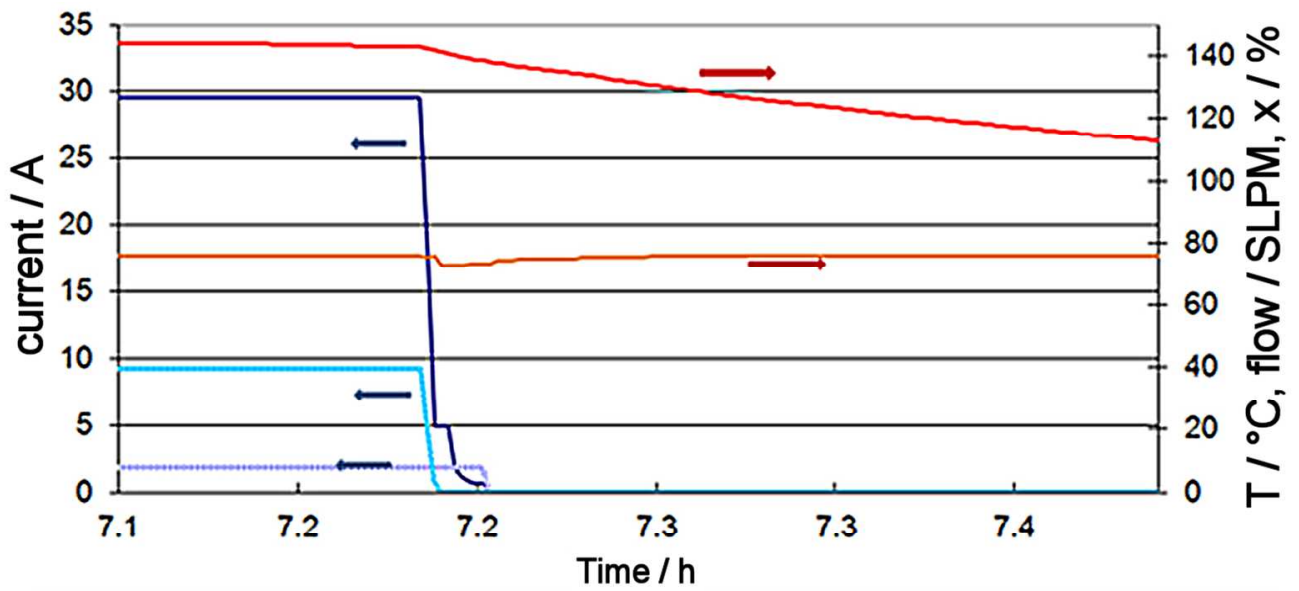

-I_Stack/A $-\mathrm{QH} 2$ _actual/SLPM $\quad$ Qair_actual/SLPM $-\mathrm{T}_{-} \mathrm{Stack} /{ }^{\circ} \mathrm{C} \quad$-N2/\%

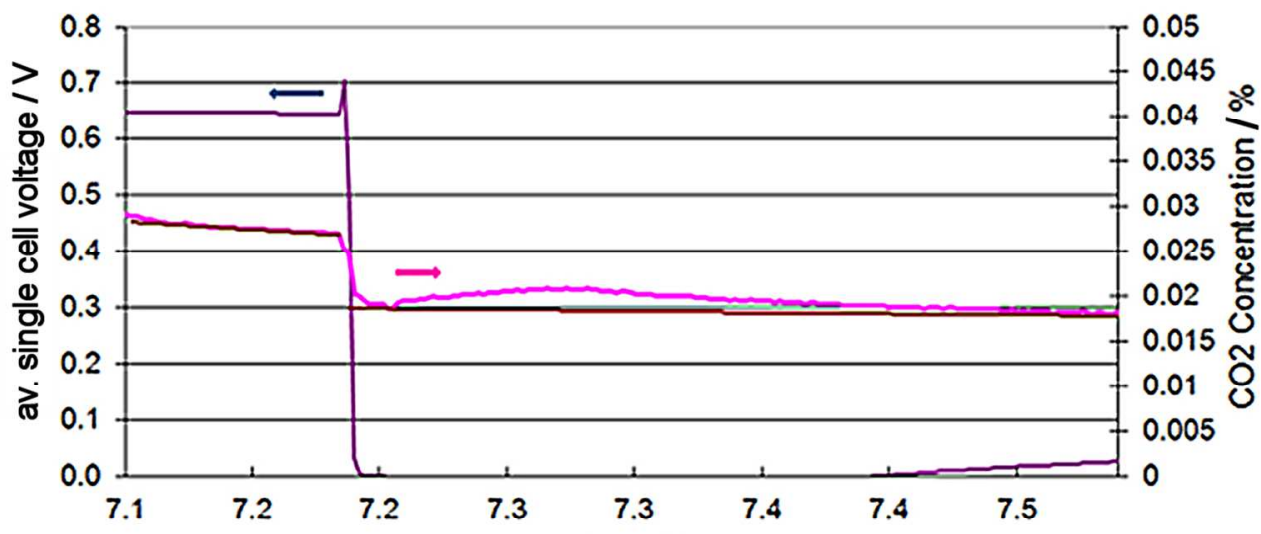

Time $/ \mathrm{h}$

-SCVave/V -

Figure 7: Stop procedure with protecting gas at $140^{\circ} \mathrm{C}$

$121 \times 123 \mathrm{~mm}(300 \times 300$ DPI $)$ 


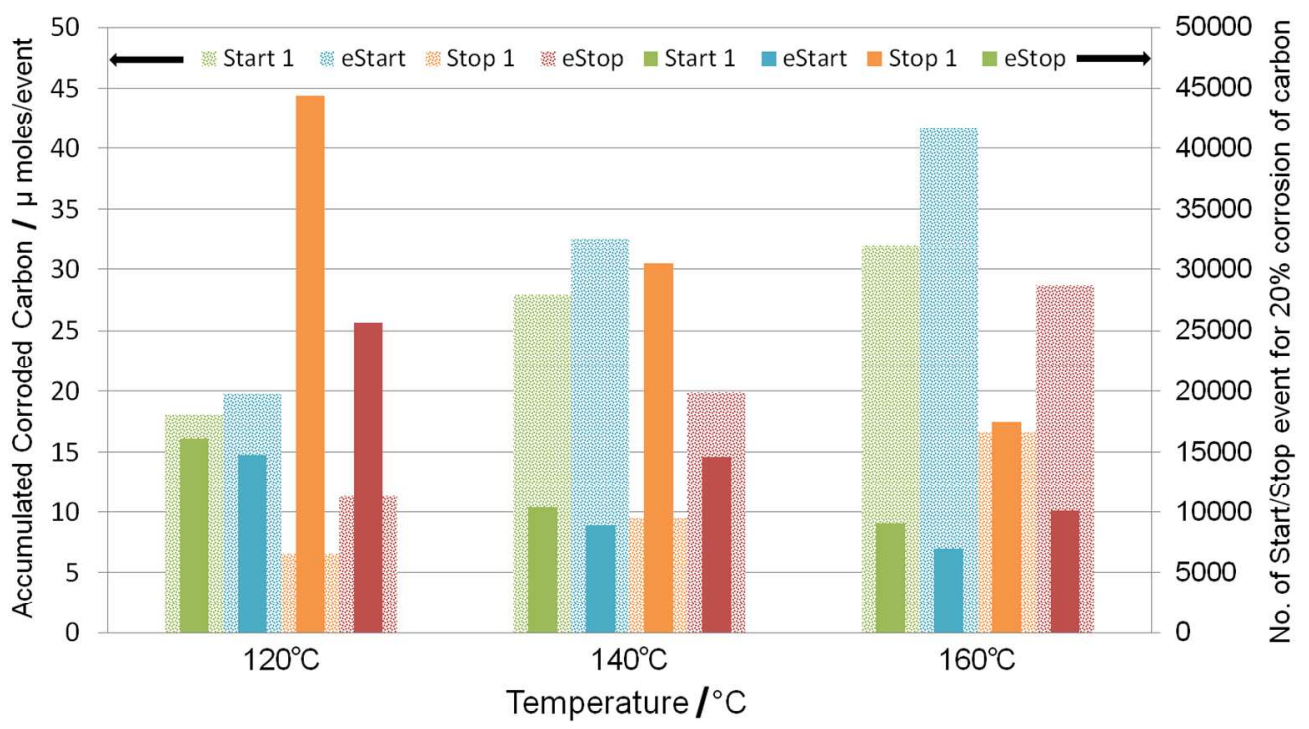

Figure 8: Accumulated corroded carbon for startup and shutdown events and its corresponding prediction of lifetime (numbers of start resp. stop events for $20 \%$ corrosion of carbon) as a function of temperature.

$127 \times 69 \mathrm{~mm}(300 \times 300 \mathrm{DPI})$ 